\title{
ARTÍCULOS
}

\section{Phenotypic variation of basic wood density in Pinus ponderosa plus trees}

\author{
Variación fenotípica de la densidad básica de la madera de árboles plus de Pinus ponderosa
}

\author{
Alejandro Martinez-Meier ${ }^{\mathrm{a}}$, Leonardo Gallo $^{\mathrm{a}}$, Mario Pastorino ${ }^{\mathrm{a}, \mathrm{b}}$, Víctor Mondino ${ }^{\mathrm{c}}$, Philippe Rozenberg ${ }^{\mathrm{d}}$

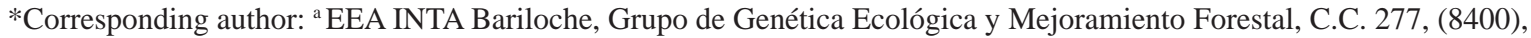 \\ San Carlos de Bariloche, Río Negro, Argentina, tel.: 54-2944-422731, almarti@bariloche.inta.gov.ar \\ ${ }^{\mathrm{b}}$ Consejo Nacional de Investigaciones Científicas y Técnicas (CONICET). \\ ${ }^{c}$ EEA INTA Esquel, Estación Agroforestal Trevelin, Trevelin, Chubut, Argentina. \\ ${ }^{\mathrm{d}}$ INRA Orléans, Unité d’Amélioration, Génétique et Physiologie Forestières, Orléans, France.
}

\begin{abstract}
SUMMARY
Phenotypic selection generally reduces the variability of both the selected trait and other associated characteristics. Some species show a negative strong relationship between growth traits and wood density. In the present study, basic wood density was assessed in a group of 23 control trees and 25 Pinus ponderosa plus trees, selected for growth and form traits in the Argentine Patagonia region. Trees were sampled in four different sites from the environmental and silvicultural point of view. We aim to study if the phenotypic variation in wood density is somehow influenced by the selection for productivity and form. The average wood density of plus trees was $0.37 \mathrm{~g} \mathrm{~cm}^{-3}$, ranging from 0.29 to $0.46 \mathrm{~g} \mathrm{~cm}^{-3}$. These values were not significantly different to control trees and were similar to those previously found in $P$. ponderosa plantations growing in the region. Wood density of the improved population, represented by plus trees did not differ from that of base population from which plus trees were selected. Significant differences were found in wood basic density among sites and age-classes. The phenotypic variation of the increment of wood density from pith to bark and among trees was different from zero. Not significant association was found between wood basic density and growth and form traits, except for stem straightness. It would be possible to identify high wood density trees at half of the rotation age.
\end{abstract}

Key words: specific wood density, repeated measurements, genetic breeding, Patagonian, Argentine.

\section{RESUMEN}

La selección fenotípica generalmente reduce la variabilidad de los caracteres seleccionados y la de los caracteres asociados. Algunas especies muestran asociación negativa entre crecimiento y densidad de la madera. En este estudio, se evaluó la densidad básica de la madera en un grupo de 23 árboles control y 25 árboles plus de Pinus ponderosa seleccionados por criterios de crecimiento y forma en la región norpatagónica de Argentina. Las muestras provinieron de cuatro sitios con diferente clima y silvicultura. El objetivo fue determinar si la variación fenotípica de la densidad de la madera pudo haber sido afectada por la selección para productividad y forma. La densidad media de la madera de los arboles plus fue de $0,37 \mathrm{~g} \mathrm{~cm}^{-3}$, variando desde 0,29 hasta $0,46 \mathrm{~g} \mathrm{~cm}^{-3}$. Estos valores no fueron significativamente diferentes a los registrados en los árboles control y similares a los previamente registrados para $P$. ponderosa creciendo en la región. La densidad de la madera de la población de mejora (árboles plus) no difirió de la población base donde fue seleccionada. Diferencias significativas para la densidad de la madera se pudieron establecer entre sitios y clases de edad. El incremento de la densidad desde la médula hacia la corteza y la variación fenotípica entre árboles fue significativamente diferente de cero. La densidad no se encontró asociada a las características de crecimiento y forma, por las cuales los árboles plus fueron seleccionados, excepto con la rectitud de fuste. Sería posible identificar árboles de alta densidad básica cerca de la mitad del turno de rotación.

Palabras clave: densidad básica de la madera, medidas repetidas, mejoramiento genético, Patagonia, Argentina.

\section{INTRODUCTION}

Ponderosa pine (Pinus ponderosa Dougl. ex Laws) was introduced in the Argentinean Patagonia at the beginning of the XXth century. Nevertheless, the first plantations for sawmill wood production were established in 1970. A breeding program was initiated in 1998, with the aim of improving growth rate and form traits. Plus trees were phenotypically selected by comparison to control trees growing in the same microenvironmental conditions (Ledig 1973).

The possible genetic gain in growth could have an indirect effect on wood properties (Zobel and Jett 1995), due to a possible unfavourable genetic correlation between growth and wood quality. Selection for growth might thus lead to a direct decrease of wood density. Unfavourable correlations between growth and wood quality seem to predominate, at least in some species like douglas-fir 
(Pseudotsuga menziesii (Mirb.) Franco) (Bastien et al. 1985), loblolly pine (Pinus taeda L.) (Paludzyszyn et al. 2005) and radiata pine (Pinus radiata D. Don) (Baltinus et al. 2007, Wu et al. 2008). However, lack of association between growth rate and wood density has also been reported in other pines such as maritime pine (Pinus pinaster Ait.) (Gaspar et al. 2009), and ponderosa pine (McKimmy and King 1980).

Wood density is known to be affected by environmental conditions, including climate, resource availability, silviculture and cambial age (Zobel and Sprague 1998). Wood density also shows a high among-tree variation, which is partiality controlled by genetic effects (Zobel and Jett 1995). The aim of the present study is to know if the phenotypic variation in wood density for ponderosa pine trees is somehow influenced by the selection for productivity and form. If it is not the case, the breeding population represented by the plus trees would keep original levels of wood density phenotypic variation compared to the base population. If this is confirmed, a reasonable phenotypic variation is expected, and could be explored to increase wood density by selecting trees from the first generation breeding program. The specific objectives of this work are: (1) to determine the relative magnitude in wood density across sites, trees, and rings within trees, (2) to study the phenotypic relations between wood density and growth and form traits and (3) to consider the feasibility of early selection for wood density, estimating age-classes correlations for this trait. The major results are compared with other ponderosa pine studies, and some practical implications are discussed.

\section{METHODS}

Material collection. Random samples from 25 plus and 23 control trees ranging in age (at breast height) from 17 to 46 years old were collected from four different sites (table 1). One core per tree was extracted at breast height with a $12 \mathrm{~mm}$ diameter increment borer. The number of plus trees sampled in this study represents the $29 \%$ of the total number of plus trees selected within the breeding program. The four sites were very different regarding their climatic conditions and silvicultural management. Annual precipitations range from $2,500 \mathrm{~mm}$ in the western site to $670 \mathrm{~mm}$ in the eastern one; the number of trees per hectare varies from 300 to 1,400 .

Cores were processed in the Laboratory of Wood Technology of the Centro de Investigación y Extensión Forestal Andino Patagónico (CIEFAP) in order to measure basic wood density.

Basic wood density determination. Cores were cut to obtain sub-samples of at least three consecutive rings compatible for wood density determination methodology. First we estimated anhydrous mass (dry weight). The subsamples were oven-dried at $103^{\circ} \mathrm{C} \pm 2{ }^{\circ} \mathrm{C}$ until constant weight, which was recorded with a $0.001 \mathrm{~g}$ precision scale. Saturated volume was measured through the water displacement method. Sub-samples were submerged in water and a negative pressure of $1 \mathrm{Mpa}$ was applied intermittently until sub-samples reached at least $150 \%$ moisture content following the same procedure described in Jovanovski et al. (2002, 2005). Wood densities were computed as the quotient between the dry weight and the volume of each sub-sample.

Data analysis. Only plus trees were evaluated to study the relationship between density and form traits. Whereas, to study the phenotypic variance components and the correlations among age-classes, we took into account the plus and control trees.

Phenotypic variance components of wood density. Each sub-sample was assigned to an age-class according to the average cambial age of the existent rings on it. All the trees were used to analyse juvenile wood. However, in order to study the phenotypic variation of the juvenile-mature wood, only trees from the two oldest sites (sites 1 and 2) were used.

Table 1. Plus and control trees sampling in each sites. Árboles plus y control muestreados en cada sitio.

\begin{tabular}{lcccc}
\hline \multirow{2}{*}{ Description } & \multicolumn{3}{c}{ Sites } \\
\cline { 2 - 5 } & 1 & 2 & 3 & 4 \\
\hline Latitude S & $43^{\circ} 07^{\prime} 59^{\prime \prime}$ & $40^{\circ} 09^{\prime} 20^{\prime \prime}$ & $39^{\circ} 19^{\prime} 21^{\prime \prime}$ & $37^{\circ} 11^{\prime} 49^{\prime \prime}$ \\
Longitude W & $71^{\circ} 33^{\prime} 42^{\prime \prime}$ & $71^{\circ} 33^{\prime} 37^{\prime}$ & $70^{\circ} 57^{\prime} 17^{\prime \prime}$ & $70^{\circ} 36^{\prime} 05^{\prime \prime}$ \\
Altitude (m) & 450 & 750 & 1,180 & 1,680 \\
Number of trees (plus-control) $^{*}$ & $7-10$ & $5-5$ & $7-4$ & $6-4$ \\
Age (years) & $38(7)$ & $46(11)$ & $18(3)$ & $17(5)$ \\
Mean annual precipitation (mm) $_{\text {Trees ha }^{-1}}$ & 1,200 & 2,500 & 1,200 & 670 \\
\hline
\end{tabular}

${ }^{*}$ Number of plus and control trees samples per site.

** Average and standard error (in parenthesis) of age at breast height. 
A linear mixed-effects model was used to study the phenotypic variation of wood density. All the sub-samples measurements taken of a same tree were treated as repeated measurements of wood density upon the same tree. The model was computed in R ( R Development Core Team 2010) using the lmer function:

$$
\mathrm{y}_{\mathrm{ijkl}}=\mu+\tau_{\mathrm{i}}+\beta_{\mathrm{j}}+\alpha_{\mathrm{k}}+\mathrm{a}_{\mathrm{i}(\mathrm{l}(\mathrm{k}))}+\varepsilon_{\mathrm{ijkl}}
$$

Where,

$\mathrm{y}_{\mathrm{ijkl}}={ }_{i j k l} h t$ observed sub-sample wood density value.

$\mu$ = overall mean effect.

$\tau_{\mathrm{i}}=$ fixed effect of ${ }_{i}$ th age-class to which each sub-sample belongs.

$\beta_{\mathrm{j}}=$ fixed effect of ${ }_{j}$ th type of tree (plus or control).

$\alpha_{\mathrm{k}}=$ fixed effect of ${ }_{k}$ th site.

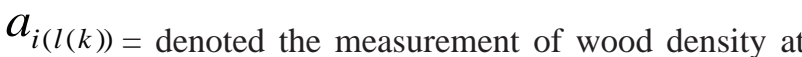
the corresponding ${ }_{i}$ th age-class on the th tree nested in the th site.

$\varepsilon_{\mathrm{ijkl}}=$ random error.

Significance of the fixed and random levels was computed using the likelihood ratio test $(P<0.05)$, comparing the complete model with a reduced model without the factor of interest. Maximum likelihood (ML) and restricted maximum likelihood (REML) methods were used for fixed and random levels respectively (Faraway 2006).

Relationships between wood density and growth and form traits. Stem straightness, branching quality $(\mathrm{BN}=$ branches number, $\mathrm{BA}=$ branches angle, $\mathrm{BD}=$ branches diameter) and crown quality (CQ) were the form traits considered, together with diameter growth (DG), for plus trees selection. A threshold diameter was the first selection criterion to identify putative plus trees in the commercial plantation:

$T D=$ meanBHD $+s d$

Where,

TD = threshold diameter.

meanBHD = mean breast height stand diameter.

sd = standard deviation of the mean breast height diameter.

The search of plus trees was oriented to the more vigorous trees, with straight and cylindrical stems, reduced and cylindrical crowns, thin short branches and with angles of insertion near to $90^{\circ}$. Each plus tree was evaluated with respect to the average of the control trees according to a score given to each selection criterion. A positive or negative value was assigned following the superiority or inferiority of the plus tree based on an assigned consideration to each variable. Thus for example, for the diameter growth, an extra point was assigned to each plus tree by every $10 \%$ of superiority with respect to the average diameters of the control trees. For further details of the selection methodology, as on the selection criteria and plus trees evaluation see Martinez-Meier et al. (2005).

The mean wood density of each tree (stem wood density at breast height) was computed. As our data do not show a bivariate normal distribution, Kendall rank correlation and its p-value on a two-sided test were computed to analyse the association between the wood density and the relative performance of plus tree in growth and form traits. Kendall library was used in R (Development Core Team 2010).

Correlation among age classes. Pearson's correlation coefficients were computed between wood density values at age 20 and wood density at ages 25, 30, 35 and 40 years considering the plus and control trees from sites 1 and 2 . Pearson correlation coefficients were estimated using the cor.test function in R (R Development Core Team 2010).

\section{RESULTS}

Average wood density for juvenile wood was very similar to juvenile-mature wood, averaging 0.37 and $0.36 \mathrm{~g} \mathrm{~cm}^{-3}$, and ranging from 0.29 to $0.46 \mathrm{~g} \mathrm{~cm}^{-3}$ in plus and control trees respectively.

The fixed effect of type of tree was not significant for juvenile wood $(P=0.6086)$ and juvenile-mature wood $(P=0.5613)$ analyses. Age-class and site were significant for juvenile wood $(P=0.0016$ and $P<0.001$, respectively) and for juvenile-mature wood $(P<0.001$ and $P=0.0261$, respectively) (table 2).

In the juvenile wood analysis, the estimated wood density of plus trees (reference levels in the model) increased $0.008 \mathrm{~g} \mathrm{~cm}^{-3}$ for each increment of age-class. Site 4 was the site with the highest average density $\left(0.41 \mathrm{~g} \mathrm{~cm}^{-3}\right)$, while site 1 , reference level in the model, was a site with lower average density. These sites are climatically contrasting and differ strongly in their latitude (site 4 northern site, and site 1 southern site). A more pronounced increment of wood density for each increment of age-class was estimated for the juvenile-mature wood analysis.

The random effects variances were different from zero and explain a significant proportion of the wood density phenotypic variance in juvenile wood and juvenile-mature wood (table 2). The variation due to wood density increases by age-class was relatively small in contrast with the variation among trees that was quite large. 
Table 2. Estimated average fixed effects and their standard error, and variance components (expressed as standard deviation) of random effects for juvenile wood and juvenile-mature wood.

Valor promedio estimado por el modelo de los efectos fijos, su correspondiente desvío estándar y los componentes de varianza de los efectos aleatorios (expresados en valores de desvío estándar) para madera juvenil y madera juvenil-madura.

\begin{tabular}{|c|c|c|}
\hline Classification level & Juvenile wood & Juvenile-mature wood \\
\hline \multicolumn{3}{|l|}{ Fixed effects } \\
\hline overall mean & $0.338(0.009)$ & $0.361(0.009)$ \\
\hline age-class & $0.008(0.026) * *$ & $0.014(0.001)^{* * *}$ \\
\hline Type & $-0.004(0.008) n s$ & $0.006(0.011) \mathrm{ns}$ \\
\hline Site 2 & $0.019(0.012) * * *$ & \\
\hline Site 3 & $0.014(0.011) * * *$ & $0.024(0.011) * *$ \\
\hline Site 4 & $0.074(0.012) * * *$ & \\
\hline \multicolumn{3}{|l|}{ Random effects } \\
\hline increment age-class|tree:site & $0.0488 * * *$ & $0.0331 * * *$ \\
\hline increment age-class & $0.0133 * * *$ & $0.0059 * * *$ \\
\hline Residual & 0.0181 & 0.0195 \\
\hline
\end{tabular}

Significant levels: *** $P<0.001 ; * * P<0.05$ and $P>0.001$; ns $P>0.05$.

A moderate significant association $(P=0.05)$ between wood density and form trait was found for stem straightness $($ tau $=-0.30)$. All the other associations were not significant (table 3).

Phenotypic correlations for wood density between 20 year age-class and the following ones (25, 30, 35 and 40) were significant $(P<0.001)$, reaching $r=0.85$ between the 20 and 25 year age-classes, and decreasing for the relations with older age-classes $(r=0.78, r=0.69, r=0.58$ between 20 and 30, between 20 and 35 and between 20 and 40 year age-class respectively).

\section{DISCUSSION}

Average wood density in the selected trees is similar to those in the control trees. In addition, wood density in the plus trees is similar to those reported by other authors (Jovanoski et al. 2002) for unselected dominant and codominant trees growing in the region. Nevertheless, the

Table 3. Tau Kendall's rank coefficients and two-sided associated $P$-values between wood density and growth and form traits considered for the selection of ponderosa pine plus-trees $(n=25)$.

Coeficiente de correlación de rangos (tau) y su valor de probabilidad $P$ asociada entre la densidad de la madera y los criterios de selección por crecimiento y forma de los árboles plus de pino ponderosa $(\mathrm{n}=25)$.

\begin{tabular}{lcc}
\hline Selection criteria & Tau & $P$ \\
\hline Growth diameter & 0.14 & 0.36 \\
Stem straightness & -0.30 & 0.05 \\
Branches number & 0.18 & 0.27 \\
Branches angle & 0.14 & 0.39 \\
Branches diameter & -0.22 & 0.16 \\
Quality of crown & 0.06 & 0.71 \\
\hline
\end{tabular}

wood density variation is lower than that observed by Jovanoski et al. (2002). Jovanoski et al. (2002) attribute the exceptional high density values $\left(0.78 \mathrm{~g} \mathrm{~cm}^{-3}\right)$ found in their work to compression-wood. The probability of finding high density values due to compression-wood in the superior trees, selected for growth and form, is, however, very low.

Wood density values reported in this study are also similar to those registered by other authors for unselected ponderosa pine trees (Burdon and Low 1991, Burdon et al. 1991, Koch and Fins 2000), although Markstrom et al. (1983) found higher average wood density values using samples from managed and non-managed stands in their natural range.

Significant differences among sites for wood density properties are reported for many species (Zobel and Sprague 1998, Larson et al. 2001, Jokela et al. 2004, Gundogan et al. 2005). The ponderosa's pine plantation area in the Patagonian region is characterized by a strong west-east precipitation gradient. Site 4 (included only in juvenile wood analysis), the site with higher juvenile wood density, represents the extreme north and east area. It is the only site with low annual precipitations. Site 3 (another juvenile wood site), is a site with lower wood density. In this site, there are a low number of trees per hectare $(300-500$ trees $\mathrm{ha}^{-1}$ ) and precipitation over $1,200 \mathrm{~mm}$, while in the other sites there are from 850 to 1,400 trees ha ${ }^{-1}$. Low number of tree by hectare and high precipitation could be the combination to produce low wood density in ponderosa pine.

Environmental and silvicultural practices are considered to be relevant factors for wood density determination. Generally these factors affect ring density via the effects in ring width (Guilley et al. 2004). Nevertheless, wood density can follow a complex pattern with important changes principally in juvenile wood (Zobel and Sprague 1998). These changes are related to ontogenetic effects, explained 
by the cambial age, environmental and silvicultural effects and the genotype effects. Microdensity profiles analysed in more than 500 ponderosa pine trees, constituting the base material for future work, show that wood density in the juvenile wood portion is strongly affected by earlywood components. High wood density values in Site 4 could be related to tracheids with narrow lumens and/or thick cell walls. This is a hypothesis that has to be confirmed due to the significant differences found for wood density among sites. It is possible to interpret that the high density values in the juvenile wood portion found in the more xeric geographic region could be related to different hydraulic properties (Alder et al. 1996, Hacke et al. 2001, Domec and Gartner 2003), which in turn could be related to different safety margins helping trees to prevent xylem embolism caused by the more adverse climate conditions during the growing season.

The age-class fixed effect is significant and consistent with the expected cambial age effect (juvenile wood and juvenile-mature wood) mentioned by different authors about many forest species (Zobel and Jett 1995) and specifically by Jovanoski et al. (2002) for ponderosa pine in the region. Wood density is one of the characteristics that better defines wood quality (Zobel and Jett 1995). Significant phenotypic variance is found among and within trees that is modelled by the intercept and slope, assuming that sub-samples taken from the same trees are repeated measurements of wood density for the corresponding tree. As many references state the high levels of heritability for wood density (Cornelius 1994, Zobel and Jett 1995), it is possible to assume that phenotypic wood density variation could be partially explained by genotypic differences among trees. This variation, which is not decreased by the growth and shape selection, will be the potential phenotypic variation to exploit in future selections within the planted progeny trials to improve wood properties.

When plus trees are to be used in seed-orchard they should, if possible, be exceptional in as many characteristics as possible (Isaac 1955). This exceptionality is described by the selection criteria, which take into account the superiority of a plus tree in relation to the control trees. Unfavourable correlations between the traits considered for selection and other non assessed traits may lead to reduced performance of the selected trees regarding the former traits. Results presented here indicate that there is no relationship between wood density and growth and/or form traits, except in the case of stem straightness. Nevertheless, the negative association between wood density and stem straightness is moderate $($ tau $=-0.30)$ and it could be just indicating the presence of compression-wood in those selected trees of low stem straightness values. The selection intensity used to select the plus trees with respect to the control trees could be the reason for finding no relationship between wood density and growth. Nevertheless, it is important to highlight that the relations described in this work are phenotypic correlations. So, it is not possible to deduce the size and the sign of the underlying genetic and environmental correlation (Falconer and Mackay 1996, White et al. 2007).

The high to moderate significant age-age phenotypic correlations between the 20 year reference age-class and all the following age-classes observed in this work indicate that it is possible to identify high density trees at mid ages that will have intermediate or high density at final rotation. McKimmy and King (1980) find that early selection of high density trees can improve mature tree density. Wu et al. (2007) and Apiolaza (2009) use this early selection criterion for screening the best individuals for wood quality.

\section{CONCLUSIONS}

Wood density and its phenotypic variation in selected plus trees were similar to those registered in unselected trees. Selection for growth and form appeared, thus, to not alter the density values and their phenotypic variation. This is important since the criteria used to select the plus trees (growth, branching and crown quality and stem straightness) could otherwise have indirect consequences in final-products, whereas the maintenance of the original phenotypic variation in wood density allows to include this trait as a selection criterion in further breeding activities.

Results also indicate that it is possible to identify high density trees at mid rotation ages with a high probability that these trees will maintain this characteristic up to harvest rotation age. Nevertheless, the results of this study are preliminary and have to be confirmed with new studies, using more refined tools as X-ray microdensity profiles. In our breeding program, no information is available yet about the genetic variation of wood characters and the genetic correlations between wood and growth. Whether the observed weak or null phenotypic correlations are indicators of no genetic correlations remains to be explored. The progeny trails planted in the region will provide this information in the future, allowing us to select desirable genotypes to produce advantageous ponderosa pine wood density properties in the region.

\section{ACKNOWLEDGEMENTS}

Research was supported by INTA (Instituto Nacional de Tecnología Agronómica)-SAGPyA (Secretaría de Agricultura, Ganadería, Pesca y Alimentos): Programa de Producción de Material de Propagación Mejorado, Subregión Andino Patagónica para Coníferas y otras especies, Proyecto Forestal de Desarrollo - BIRF, No 3948-AR. We would like to thank CIEFAP, particularly Alejandro Jovanoski and Darío Lopez who helped us to assess ponderosa pine wood density. Finally, we also thank the three reviewers whose comments helped to improve the manuscript. 


\section{REFERENCES}

Alder NN, JS Sperry, WT Pockman. 1996. Roots and stem xylem embolism, stomatal conductance, and leaf turgor in Acer grandidentatum populations along a soil moisture gradient. Oecologia 105: 293-301.

Apiolaza LA. 2009. Very early selection for solid wood quality: screening for early winners. Annals of Forest Science 66 (2009) 60. DOI: 10.1051/forest/2009047. Accessed Sep 7, 2009. Available in: http://www.afs-journal.org.

Baltinus B, H Wu, M Powell. 2007. Inheritance of density, microfibril angle, and modulus of elasticity in juvenile wood of Pinus radiata at two locations in Australia. Canadian Journal of Forest Research 37(11): 2164-2174.

Bastien JC, B Roman-Amat, G Vonnet. 1985. Natural variability of some wood quality traits of coastal Douglas-fir in a French progeny test: implications on breeding strategy. Proceeding IUFRO, Working party S2.02.05: on breeding strategies for Douglas-fir as an introduced species. $18 \mathrm{p}$.

Burdon R, C Low C. 1991. Performance of Pinus ponderosa and Pinus jeffreyi provenances in New Zealand. Canadian Journal of Forest Research 21 (9): 1401-1414.

Burdon R, J Miller, F Knowles. 1991. Introduced Forest Trees in New Zealand. Recognition, Role and Seed Source., Ponderosa and Jeffrey Pines. Rotoura, New Zealand, Forest Research Institute. Bulletin Number 124. 23 p.

Cornelius J. 1994. Heritabilities and additive genetic coefficients of variation in forest trees. Canadian Journal of Forestry Research 24: 372-379.

Domec JC, BL Gartner. 2003. Relationship between growth rates and xylem hydraulic characteristics in young, mature and old-growth ponderosa pine trees. Plant, Cell \& Environment 26: 471-483.

Falconer DS, TF Mackay. 1996. Introduction to Quantitative Genetics. Harlow, UK. Longman Group Ltd,. 464 p.

Faraway JJ. 2006. Extending the linear model with R. Generalized linear, mixed effects and nonparametric regression models. Boca Raton, USA. Chapman and Hall/CRC. 301 p.

Gaspar MJ, JL Lousada, JC Rodrigues, A Aguiar, MH Almeida. 2009. Does selecting for improved growth affect wood quality of Pinus pinaster in Portugal? Forest Ecology and Management 258: 115-121.

Guilley E, Hervé JC, Nepveu G. 2004. The influence of site quality, silviculture and region on wood density mixed model in Quercus petraea Liebl. Forest Ecology and Management 189: 111-121.

Gundogan R, I Bektas, MH Alma, A Yuksel. 2005. Relationship between site index and some physical properties of Calabrian Pine. Forest Products Journal 55 (1): 45-48.

Hacke UG, JS Sperry, WT Pockman, SD Davis, KA McCulloh. 2001. Trends in wood density and structure are linked to prevention of xylem implosion by negative pressure. Oecologia 126: 457-461.

Isaac L. 1955. Tentative guides for the selection of plus trees and superior stands in Douglas-fir. Portland, USA, USDA Forest Service. Pacific Northwest Forest and Range Experiment Station, 9 pp. Research Note Number 122.
Jokela EJ, PM Dougherty, TA Martin. 2004. Production dynamics of intensively managed loblolly pine stands in the southern United States: a synthesis of seven long-term experiments. Forest Ecology and Management 192 (1): 117-130.

Jovanoski A, M Jaramillo, G Loguercio, S Antequera. 2002. Densidad de la madera de Pinus ponderosa (Dougl. Ex Laws) en tres localidades de Argentina. Bosque 23 (2): 99-104.

Jovanovski A., M Davel, D Mohr-Bell. 2005. Densidad básica de la madera de Pseudotsuga menziesii (Mirb.) Franco en la Patagonia. Investigaciones Agrarias: Sistemas Recursos Forestales 14 (2): 153-160.

Koch L, L Fins. 2000. Genetic variation in wood specific gravity from progeny tests of ponderosa pine (Pinus ponderosa Laws.) in Northern Idaho and Western Montana. Silvae Genetica 49 (4/5): 174-181.

Larson P, D Kretschmann, A Clark, J Isebrands. 2001. Formation and properties of juvenile wood in southern pines: a synopsis. Gen. Tech. Rep. FPL-GTR-129, Madison, Wisconsin, USA. USDA Forest Service, Forest Products Laboratory. $42 \mathrm{p}$.

Ledig FT. 1973. The application of mass selection in tree improvement. Proceedings of the Twentieth Northeastern Forest Tree Improvement Conference. Durham, New Hampshire. $14 \mathrm{p}$.

Markstrom D, H Troxell, C Boldt. 1983. Wood properties of immature ponderosa pine after thinning. Forest Products Journal 33 (4): 33-36.

Martinez-Meier A, L Gallo, V Mondino. 2005. Estrategia de Mejoramiento Genético de Pino Ponderosa y Pino Oregón. IDIA XXI (8): 185-190.

McKimmy MD, JP King. 1980. Strength relationships in young ponderosa pine of known parentage. Wood Science 12 (3): 165-167.

Paludzyszyn Filho E, V Shimoyama, A Mora. 2005. Seleçao precoce pra incremento simultaneo do crescimento e da qualidade da madeira em Pinus taeda L. Boletim de Pesquisa Florestal 46: 31-46.

R Development Core Team. 2010. R: A language and environment for statistical computing. R Foundation for Statistical Computing. Vienna, Austria. ISBN 3-900051-07-0, URL http://www.R-project.org.

White T, T Adams, D Neale. 2007. Forest Genetics. Cambridge, USA. CABI Publishing. 682 p.

Wright J. 1976. Introduction to Forest Genetics. New York, USA. Academic Press, Inc. 463 p.

Wu H, MB Powell, JLYang, M Ivcovic, TA MacRae. 2007. Efficiency of early selection for rotation-aged wood quality traits in radiata pine. Annals of Forest Science 64: 1-9.

Wu H, M Ivkovic, WJ Gapare, AC Matheson, BS Baltunis, MB Powell, TA Mcrae. 2008. Breeding for Wood Quality and profit in Pinus radiata: a review of genetic parameter estimates and implications for breeding and deployment. New Zealand Journal of Forestry Science 38: 56-87.

Zobel B, JB Jett. 1995. Genetics of wood production. BerlinHeidelberg, Germany. Springer-Verlag. 337 p.

Zobel B, J Sprague. 1998. Juvenile Wood in Forest Trees. BerlinHeidelberg, Germany. Springer-Verlag. 300 p. 